\title{
Materialism and the Activity of Matter in Seventeenth-Century European Philosophy
}

\author{
Stewart Duncan
}

23 May 2016

\section{Introduction}

The question of materialism about the mind might seem to be a simple one: can matter think ? $^{1}$ Asking what seventeenth-century European philosophers said in response to this question, we find that most of them - certainly most of the famous ones - said 'no', but the occasional one said 'yes'. That simple account is true, but hides a good deal of interesting, and philosophically important, detail. For one thing, seventeenth-century discussions of these issues ranged far beyond the handful of centrally canonical philosophers. Without attempting anything like a full history of those debates, we can learn something by looking around the edges of the canon, as well as at the center. In this paper I discuss a variety of seventeenth-century views about materialism.

When faced with the question, 'can matter think?', one natural response is to ask what exactly is meant by 'matter'. What features is this stuff supposed to have? Unsurprisingly, early modern debates about the nature of matter interacted with debates about whether matter could think. René Descartes (1596-1650) came close to saying that it was in the nature of matter that it could not think. Thus the narrator of his Meditations reports, in the course of an argument for the real distinction between mind and body, that "I have a distinct idea of body, in so far as this is simply an extended, non-thinking thing" (Descartes 2: 54). That is the most direct way in which views about matter's nature might

\footnotetext{
${ }^{1}$ I generally use 'matter' to refer to material, corporeal stuff, and 'bodies' to refer to individual material, corporeal things. The exceptions occur when I am using the terminology of some particular author I am discussing.
} 
interact with the issue of whether it might think. There are other, less direct but still important, connections.

Another important connection is that several philosophers argued that the passivity of matter showed that material things could not think. Such an argument - call it the Activity Argument- might go as follows.

1. Thinking is an activity, and a mind is an active thing. And

2. Matter is passive, and bodies are passive things. But

3. One cannot make an active thing out of passive things. So

4. A mind cannot be made out of bodies.

We can find this Activity Argument, or arguments like it, in the work of several early modern philosophers.

In section 3 I look at examples of the Activity Argument in the work of Ralph Cudworth (1617-1688), John Locke (1632-1704), and Gottfried Wilhelm Leibniz (16461716). Before that, in section 2, I look at materialist views, in particular those of Thomas Hobbes (1588-1679). Hobbes was perhaps the most prominent seventeenth-century materialist philosopher, and his work provides a good example of how someone in this period might think that passive matter could be formed into thinking things. In later sections I look at possible responses to the Activity Argument, focusing on views which are in some ways like Hobbes's, but which differ in that they involve the belief that matter is active. I consider, in particular, the views of John Toland (1670-1722) and Margaret Cavendish (1623?-1673).

This paper focuses on questions about the nature of the human mind - as opposed to other animals' minds - and treats them mainly as issues in metaphysics or the philosophy 
of mind. Historically these were not, however, merely technical issues in the philosophy of mind. There were several important connections to moral and religious issues. Consider three examples. First, materialism appears to make it harder to account for the possibility of an afterlife. This seems, for example, to have been one of Descartes's goals in his Meditations - to show that the mind was not material, and thus that it might be immortal. Secondly, questions about the nature of the mind connect to questions about freewill. If the movements of matter are fully causally determined, and human minds are material beings, then it looks like our beliefs, motives, and decisions will also be fully causally determined, a conclusion that many have found unacceptable. There are also complex connections, in seventeenth-century European debates, between philosophical views about freewill and religious views about, e.g., predestination. ${ }^{2}$ Thirdly, questions about the human mind lead to questions about the minds of non-human animals, questions that have their own moral and religious consequences. A consistent materialism about both human and animal minds seems to lead to the view that humans are not distinctive and special. A dualist view such as Descartes's, on which humans have an immaterial soul and other animals do not, preserves that distinction, at the cost of saying puzzling things about animal minds. It seems implausible, for example, to say that non-human animals have no sensations. Solving these puzzles by attributing an immaterial mind to those animals would have its own problems though. In particular, religious puzzles threaten to arise, as one might seem to have introduced immortal souls of animals.

\section{Two seventeenth-century materialist views}

\footnotetext{
${ }^{2}$ On some related debates about free will see Harris and Jackson.
} 


\subsection{Hobbesian materialism}

Hobbes believed that certain bodies - in particular, living human bodies - could think, purely as a result of the motions of their parts. Consider the story about the mind that he tells in the first few chapters of his 1651 Leviathan. There he builds up an explanation of mental abilities - perception, imagination, memory, reason, passions, etc. - referring only to material things and their motions. Hobbes thus provides an example of mechanist materialism - materialism in which the mind is constructed from parts, the structure and motion of which give rise to surprising powers. There is a lot that needs explaining, if one is to have a fully developed materialist account of the mind of this sort. Hobbes was far from having all the details worked out, but even so, he had a good deal to say. Here I briefly consider three parts of his theory: his initial explanation of perception; his subsequent explanation of memory and imagination; and his view about the important role of language.

Consider first the discussion of perception with which Hobbes begins Leviathan: Concerning the Thoughts of man, I will consider them first Singly, and afterwards in Trayne, or dependance upon one another. Singly, they are every one a Representation or Apparence, of some quality, or other Accident of a body without us; which is commonly called an Object. Which Object worketh on the Eyes, Eares, and other parts of mans body; and by diversity of working, produceth diversity of Apparences (Leviathan 22).

Hobbes explains perception in terms of motion and pressure. In his story, the external object perceived presses on the perceiver's body (either directly, or indirectly via the medium), which pressure is then passed on into the body through the nerves, until it reaches the brain and the heart. There, in the heart, there is "a resistance, or counter-pressure, or 
endeavour of the heart" (Leviathan 22). This pressure is, or gives rise to, the sensation itself. The fact that this final pressure is outwards is supposed to explain why perception seems to be of something outside the body. ${ }^{3}$

Hobbes is not precise about what the dependence relation between the internal motions and the sensation is: he moves from talking about motions and pressures to talking about sense, appearance, and mental images, clearly thinking that the latter depend on the former, but not saying exactly how. That said, he clearly does think that bodies are the only substances involved in perception. It is obviously not unusual to think that material objects, including material parts of human beings, have an important role to play in perception. Still, it is notable that Hobbes gave a purely material account of perception. Here we might contrast Descartes, who argued that "We know for certain that it is the soul which has sensory perceptions, and not the body" (Descartes 1: 164). The soul that Descartes mentions here is immaterial. Hobbes's account, on the other hand, refers only to material objects and their motions.

Hobbes's account of the mind continues with a story about memory and imagination. Again, these are explained purely materially, as a result of motions in us. The thoughts that remain in our mind after perception are described as "decaying sense" (Leviathan 26), the motions of those perceptions being obscured by all the motions of other perceptions that come afterwards. This material account extends to understanding as well, which Hobbes takes to be another aspect of imagination: "The Imagination that is raysed ... by words, or other voluntary signes, is that we generally call Understanding; and is common to Man and Beast" (Leviathan 36). Hobbes did think there were differences between human and

\footnotetext{
${ }^{3}$ For other accounts see Elements of Law, ch.2 and De Corpore, ch.25.
} 
animal cognition: most importantly, humans have language, which allows them to think general thoughts, and acquire scientific knowledge, but also opens up the possibility of speaking absurdly, and of self deception. Hobbes maintained, however, that none of humans' extra cognitive powers demanded an immaterial explanation. All of them, ultimately, were to be explained by the motions of parts of our bodies.

\subsection{Locke and the superaddition of thought to matter}

Hobbes gives us a clear and straightforward example of a seventeenth-century European materialist, but he was not the only one. ${ }^{4}$ An intriguing further example occurs in some of John Locke's discussions. Locke rejected Hobbes's sort of materialism, but thought that another sort of materialism might perhaps be true.

Locke suggested that different sort of materialism when he said that "GOD can, if he pleases, superadd to Matter a faculty of Thinking" (Essay 4.3.6). "For", Locke says, I see no contradiction in it, that the first eternal thinking thing should, if he pleased, give to certain Systems of created senseless matter, put together as he thinks fit, some degrees of sense, perception, and thought (Essay 4.3.6).

Whatever exactly superaddition is, it seems to be more than mere arrangement, so this view is not the same as Hobbes's mechanist materialism. Rather, it is the view that there could be a finite, created material mind, if God did something over and above arranging and moving parts. ${ }^{5}$ It is nevertheless a sort of materialism about the mind, which is based on, or at least

\footnotetext{
${ }^{4}$ One controversial example is that of Benedict Spinoza (1632-1677), who some have thought to have been a materialist. The interpretation of Spinoza's metaphysics is puzzling enough that others have plausibly read him as an idealist.

${ }^{5}$ On superaddition see Ayers 2:142-53, Downing, 'Status', and Wilson 196-214.
} 
compatible with, a belief in the passivity of matter. ${ }^{6}$ It was also a view that generated considerable debate among Locke's contemporaries. ${ }^{7}$

\section{The Activity Argument}

Recall the Activity Argument that I introduced in section 1:

1. Thinking is an activity, and a mind is an active thing. And

2. Matter is passive, and bodies are passive things. But

3. One cannot make an active thing out of passive things. So

4. A mind cannot be made out of bodies.

This is an objection to materialism about the human mind, particularly of the Hobbesian and Lockean sorts.

\subsection{Activity}

What is meant by 'active' here? The question is whether matter can move itself, or merely receive and pass on motion that originated outside it. The active in this sense is the selfmoving - or more broadly, the self-changing. For matter in this sense to be active, it must be able to be the ultimate finite source of motion (or change more generally) rather than merely passing it on.

\footnotetext{
${ }^{6}$ In Essay 2.21.2 Locke allows that matter might have some active powers, but seems skeptical about whether it does, and says that we get a better idea of active power by looking at our minds.

${ }^{7}$ For examples of early modern criticism of Locke's view see Mary Astell's discussion in her Christian Religion (sections 262-9, pp. 253-61); Pierre Bayle's discussion in Note M to the article "Dichaearchus" in his Dictionary (Bayle 72-4); the comments of Samuel Clarke in his correspondence with Anthony Collins (Clarke and Collins); and Leibniz's comments, such as those in the Preface to the New Essays (Philosophical Essays 300-5).
} 
Consider the bodies in Hobbes's story about perception. Aside from the perceiver's own body, there is an external body perceived, and there are also bodies in between - air is body, not empty space. It seems natural to say that, in Hobbes's view, the intervening bodies are just passing on motion, not actively generating it themselves. What about the perceived object? When an isolated case of perception is described, the observed body looks to be the originator of the motion. Hobbes thinks however that it is also really a passive thing, which can only pass on motion it has received from a neighboring body.

Hobbes’s contemporary Henry More (1614-1687) criticized him on several fronts. On this issue he agreed with him though, arguing that matter is not active: it cannot move itself, but only pass on motion that originated in some other kind of thing (namely spirit).

The next property is Self-motion, which must of necessity be an Attribute of something or other; For by Self-motion I understand nothing else but Self-activity, which must appertain to a Subject active of it self. Now what is simply active of it self, can no more cease to be active then to Be; which is a sign that Matter is not active of it self, because it is reducible to Rest: Which is an Argument not only that Self-activity belongs to a Spirit, but that there is such a thing as a Spirit in the world, from which activity is communicated to Matter (More 42).

More's reason why matter is not active is that matter sometimes is at rest. Thus it is not essentially a moving thing, for sometimes it is not moving at all. More appears here to assume both that an object that essentially has a feature must always have (a degree of) that feature, and that rest is not a degree of motion. The detailed interpretation of More's argument aside though, one should at least notice that there was a genuine question at the 
time as to whether matter was active in this sense. ${ }^{8}$ More and Hobbes agreed, but many others did not. ${ }^{9}$

\subsection{Three versions of the Activity Argument}

We find something like the Activity Argument in Cudworth's 1678 True Intellectual System of the Universe:

For Body being nothing but Antitypous Extension, or Resisting Bulk, nothing but mere Outside, Aliud extra Aliud, together with Passive Capability, hath no Internal Energy, Selfactivity, or Life belonging to it; it is not able so much as to Move it self, and therefore much less can it Artificially direct its own Motion (163).

Here Cudworth argues that because body is not active, it can neither cause its own motion, nor "artificially direct" that motion - it cannot decide what that motion should be, or exercise control over it. Cudworth was not the only one to draw attention to a distinction between active and passive here. ${ }^{10}$

John Locke apparently echoes Cudworth's argument when he argues that matter alone - "a dead inactive Lump", in one example - "cannot produce in it self so much as Motion", never mind thought (Essay 4.10.10). But perhaps Locke is better read as giving two arguments: a first argument that matter cannot produce activity (motion), and a second argument that it cannot (even if you add motion) produce thought. ${ }^{11}$

\footnotetext{
${ }^{8}$ On More's views about matter, including self-activity (or its absence) see Reid (237-278).

${ }^{9}$ Here see section 4 below.

${ }^{10}$ Later and in a very different context we find Hume arguing that "an active principle can never be founded on an inactive" (Treatise 3.1.7).

${ }^{11}$ On Locke and Cudworth see Ayers 2:169-83.
} 
The Activity Argument can be seen more clearly in some of the work of Leibniz. Leibniz was opposed to both the Hobbesian and the Lockean forms of materialism. He talked of "the wicked doctrine of those who, following Epicurus and Hobbes, believe that the soul is material" (New System 112). And he cited Locke's view as an example of the way that "NATURAL RELIGION itself seems to decay [in England] very much" (Philosophcal Essays 320). Leibniz had several objections to materialist views. Among them was the Activity Argument. ${ }^{12}$

Leibniz understood thought (perception, in his terminology) to be a sort of action. Matter, however - at least, matter as many philosophers understand it - is purely passive. Thus, an objection to materialism arises. As Leibniz puts the point, very directly, in a 1710 piece on the souls of men and beasts: "perception cannot be deduced from bare matter since it consists in some action" (Shorter 63). ${ }^{13}$ This seems, quite straightforwardly, to be a version of the Activity Argument against materialism.

\subsection{Responses to the Activity Argument}

Can the Hobbesian and Lockean versions of materialism be defended against the Activity Argument? The superaddition theorist seems to have a ready response. For they might simply say that, if God were to add the power of thought to matter, God would thereby add an active power to matter. Thus, although matter in general is not active, matter with the superadded power of thought is active. ${ }^{14}$

\footnotetext{
${ }^{12}$ For more detailed recent discussions of this and related issues, see Duncan, 'Mill Arguments', Lodge, and Rozemond.

${ }^{13}$ See the discussion of this text by Rozemond (11-5).

${ }^{14}$ Matter to which God has superadded thought already possesses a power that most matter does not have, one that seems not to be derived from the nature of matter itself. If it can
} 
If the Activity Argument poses a problem for anyone, it is the Hobbesian materialist. No doubt, someone already convinced of Hobbesian materialism might take its truth to show that something must be wrong with this abstract anti-materialist argument. Seeking a more detailed response, they might deny premise 3's claim that one cannot make an active thing out of passive things. Or they might deny premise 1's claim that thinking things are (in the relevant sense) active. Certainly Hobbes himself often seems inclined to think of minds as just another part of the mechanical world, working by motion, action, and reaction.

A different sort of response would involve rejecting premise 2's claim that matter is purely passive. In fact, a number of early modern philosophers thought for other reasons that matter was active. This opens up the possibility of using an active matter theory to defend materialism about the mind. Moreover, as we will see below, there were seventeenthcentury materialists who believed matter was active.

\section{Active matter}

A number of notable figures thought matter was active in something like the sense introduced in section 3. ${ }^{15}$ Pierre Gassendi (1592-1655), for example, had attributed activity to atoms, believing that there was a "natural and internal faculty or force [vis] by which atoms move and go" (LoLordo 140). Gassendi’s views were promoted in English by Walter Charleton (1620-1707). ${ }^{16}$ Thus, for example, chapter XI of Charleton's 1654 Physiologia Epicuro-Gassendo-Charltoniana is "Of the Motive Virtue, Habit, Gravity, and Levity of

possess such an unusual power because of the power and action of God, why may it not possess an unusual active power for that reason?

${ }^{15}$ On seventeenth-century belief in active matter see Garber et al. and Henry.

${ }^{16}$ On Charleton's view, and a variety of related seventeenth-century British views, see Henry. 
Concretions" (Charleton 269-292). ${ }^{17}$ Charleton claimed both that atoms possess an "essential Faculty, Mobility" and that all atoms are always in motion, "incessantly agitated" by that faculty (269). Atoms, the most basic of bodies, are essentially and constantly active. This activity gives rise to the motive virtue of compound bodies.

Leibniz provides another example of belief in active matter. The example is complicated by interpretative questions about how matter, bodies, and corporeal substances fit into Leibniz's overall metaphysical scheme. ${ }^{18}$ There are further questions about how his advocacy of a sort of active matter view relates to his promotion of the Activity Argument. Despite these complications, however, it is clear that one of Leibniz's repeated criticisms of earlier moderns such as Hobbes and Descartes was that their views of the material world omitted active force. Consider, for instance, what he said in his 1702 essay "On Body and Force, Against the Cartesians". There he "acknowledge[s] a certain active force or entelechy in body" (Philosophical Essays 250). This active force "involves an effort [conatus] or striving [tendentia] toward action [actio], so that, unless something else impedes it, action results" (252). Why should we believe that bodies contain such an active force? Leibniz appeals to "experience itself which shows that motions are in matter" (253), and asks what causes those motions. Ultimately, for Leibniz as for his opponents, the answer is God. Nevertheless, Leibniz thinks, "in particular cases, they ought to be attributed to the force God placed in things" (253). This force of Leibniz's is active in two ways. It is active in the sense opposed to occasionalism: the force is in created bodies, and is not simply the action of God. But it is

\footnotetext{
17 'Concretions' here are compound bodies.

${ }^{18}$ The problems are most obvious if we interpret Leibniz as an idealist (Adams). But they remain even if we prefer other readings. For alternative approaches, see for example Garber and Hartz.
} 
also active in the second sense: it involves an effort or striving, and its possessor is not merely a passive thing that passes on motion.

The debate about the activity of matter took a further turn towards the end of the seventeenth century, with the rise of Newtonian physics. ${ }^{19}$ The theory of Isaac Newton (1642-1727) introduced an attraction between bodies, which seemed mechanically inexplicable. Newtonians differed on how exactly to account for this attraction: acceptance of Newton's discoveries did not have to push one to a different conception of matter. But Roger Cotes (1682-1716), editor of the second edition of Newton's Principia, did write in his Preface to that edition that:

Among the primary qualities of bodies universally, either gravity will have a place, or extension, mobility, and impenetrability will not. And the nature of things either will be correctly explained by the gravity of bodies or will not be correctly explained by the extension, mobility, and impenetrability of bodies (Newton 392).

Cotes did not just argue that mechanical explanations are inadequate (given what Newton had discovered). He also suggested that a better explanation would make gravity a primary (and thus fundamental) quality of bodies. This, in its own way, would make matter active: matter could move as a result of its inherent gravitational power, without impulse from outside. Cotes's suggestion was far from universally accepted among Newtonians. But it illustrates the potential Newton's discoveries had for changing the debate about the nature of matter and bodies. More generally, the views described in this section show that it was not unusual for early modern philosophers to believe that matter was active.

\footnotetext{
${ }^{19}$ On Newtonianism and philosophy see for example Downing, "Locke's Newtonianism", Janiak, and Janiak and Schliesser.
} 


\section{Materialism with active matter}

Recall once again the Activity Argument against materialism. If one thought that matter was active, one would seem to have a ready reply. In this section, I present two views one could think of in this way - two materialist views of the time period, according to which matter was active. These are the views of John Toland and Margaret Cavendish. This is not to say they were initially presented as responses to the Activity Argument, but they do show some of the resources that were available for response.

Both Toland's view and Cavendish's involve believing that minds are material, and that matter is fundamentally active. They differ in how they think the power of thought arises. Toland's view is much like Hobbes's: it explains thought in terms of the structure and motions of the material parts of the thinking thing. Cavendish, in contrast, takes matter's power of thought to be fundamental, not derivative.

\subsection{Toland}

John Toland was at one point a Hobbesian materialist. Leibniz described him as such in 1702: "The view is Hobbes's view that there is nothing in nature but shapes and movements" (Leibniz, Klopp 364). However, Toland came to think that matter was active seemingly as a result of his engagement with Leibniz, believer in active force in the material world (Duncan, 'Toland, Leibniz'). Thus in his 1704 Letters to Serena, Toland claimed that "Matter is necessarily active as well as extended" $(5.1,164)$, and indeed that "Activity ought to enter into the Definition of Matter, [and] it ought likewise to express the Essence thereof' $(5.2,165)$. Thus, Toland became a materialist who believed in active matter. 
It is true that having this view would allow an easy response to the Activity

Argument. The active power of thinking is attributed to matter that is itself active, so there is no attempt to derive the active from the passive. However, in Toland's view, the activity of matter is apparently unrelated to the ability of material bodies to think: that is explained, as in Hobbes's view, by the arrangement and motion of parts. So a worry about how shapes and motions can give rise to thoughts might seem to remain, even though Toland's view differs from Hobbes's in what it says about the origin of that motion. Cavendish, however, avoids that problem, for she tells a strikingly different story about how matter thinks.

\subsection{Cavendish}

Cavendish held, like Hobbes and Toland, that all of the natural world is material and that there are material thinking things. Unlike Hobbes, she thought that matter was fundamentally active. Moreover, she thought that some matter had the fundamental power of thought.

We see these views in several of her works. Here I take my examples from her 1668 Ground of Natural Philosophy. In the third chapter of part I, having described some basics of her materialism, Cavendish distinguishes "two sorts of Matter, namely, that sort which is Self-moving, and that which is not Self-moving" (3). That is, there is self-moving matter, active matter. Cavendish goes on to distinguish two sorts of self-moving matter, the sensitive and the rational. As that language suggests, she thought some matter could think - and that this thinking was a basic feature of it, not the result of the structuring of its parts in a mechanically appropriate way. Thus chapter 8 of part I of the Ground: 
IF Nature were not Self-knowing, Self-living, and also Perceptive, she would run into Confusion: for, there could be neither Order, nor Method, in Ignorant motion; neither would there be distinct kinds or sorts of Creatures, nor such exact and methodical Varieties as there are: for, it is impossible to make orderly and methodical Distinctions, or distinct Orders, by Chances: Wherefore, Nature being so exact (as she is) must needs be Self-knowing and Perceptive: And though all her Parts, even the Inanimate Parts, are Self-knowing, and Self-living; yet, onely her Self-moving Parts have an active Life, and a perceptive Knowledg (7). Cavendish's vision is of matter as a fundamentally active thing, whose powers include the power of thought. Thought is not the result of mechanical structure. ${ }^{20}$ Indeed, quite the opposite - Cavendish apparently attempts to explain mechanical interaction in terms of thought. This comes across in her discussions of Hobbes and Descartes in her Philosophical Letters. For example, where Hobbes thought that pressure and reaction explained perception and thought, Cavendish argues that perception and thought explain pressure and reaction. Thus she comments in letter 18 of Part I: "I will not say, that there is no pressure or reaction in Nature, but pressure and reaction doth not make perception, for the sensitive and rational parts of matter make all perception and variety of motion".

Cavendish's view avoids the Activity Argument objection to materialism. In doing so, however, it encounters its own problems. One might wonder, of course, what the evidence is that the material world really has this fundamental feature. Beyond that, there is a serious question about how the many thinking beings that Cavendish allows relate to one

\footnotetext{
${ }^{20}$ In addition to thinking that the parts of matter could think, she seemed also to believe that the whole of rational matter taken together was a thinking thing, the "General Soul of Nature, which I name the rational Matter" (Opinions, Epistle to the Reader).
} 
another. If all the parts of nature can think and know, then my dog, my dog's left ear, and the hair at the very end of that ear can all think. The dog, a thinking thing, is made up of many smaller thinking things. But how does the thought of the dog relate to the thoughts of its parts? It is not simply the sum of them. Cavendish at one point suggests that the parts of a whole believe what the whole believes, when she argues that the various parts of nature believe in God, because nature as a whole does. ${ }^{21}$ This surprising principle would fill out the story somewhat, but does not tell us which of the beliefs of the parts are beliefs of the whole.

\section{Conclusion}

The apparently simple question of whether matter can think is complicated by debates about what matter itself is, and what it can possibly do. Materialists such as Hobbes believed that matter could think, and that this thought arose simply from the arrangement and motion of parts. Several critics objected that this was not possible, because matter is passive, thought is active, and active powers cannot arise from merely passive things. We can see this objection, the Activity Argument, in the work of Cudworth and Leibniz. Some early modern materialists, however, held views that avoided that objection, because they also believed that matter was active. Toland and Cavendish provide two examples of this. Toland continued to believe, like Hobbes, that material beings' thought arose from the structure and motion of

\footnotetext{
${ }^{21}$ That is, "if nature believes a God, all her parts, especially the sensitive and rational, which are the living and knowing parts, and are in all natural creatures, do the like, and therefore all parts and creatures in nature do adore and worship God, for any thing man can know to the contrary" (Letters, Part II, letter 1). This suggests a dependence of the thoughts of the parts on the thoughts of the whole.
} 
the beings' parts. Cavendish, however, took thought to be a fundamental and irreducible feature of active, thinking matter. 


\section{$\underline{\text { Works Cited }}$}

Adams, Robert Merrihew. Leibniæ: Determinist, Theist, Idealist. Oxford: Oxford University Press, 1994.

Astell, Mary. The Christian religion, as Profess'd by a Daughter of the Church of England. London: 1705.

Ayers, Michael. Locke. London: Routledge, 1991.

Bayle, Pierre. Historical and Critical Dictionary. Trans. R. Popkin. Indianapolis: Hackett, 1991.

Cavendish, Margaret. Ground of Natural Philosophy. London: 1668.

---. Philosophical and Physical Opinions, second edition. London, 1663.

---. Philosophical Letters. London: 1664.

Clarke, Samuel, and Anthony Collins. The Correspondence of Samuel Clarke and Anthony Collins, 1707-18. Ed. William Uzgalis. Peterborough: Broadview, 2011.

Charleton, Walter. Physiologia Epicuro-Gassendo-Charltoniana. London: 1654.

Cudworth, Ralph. The True Intellectual System of the Universe. London: 1678.

Descartes, René. The Philosophical Writings of Descartes. Trans. John Cottingham, Robert Stoothoff, and Dugald Murdoch. Cambridge: Cambridge University Press, 1984.

Downing, Lisa. 'Locke's Newtonianism and Lockean Newtonianism.' Perspectives on Science. 5:3 (1997): 285-310.

---. 'The Status of Mechanism in Locke's Essay.' Philosophical Review. 107 (1998): 381-414.

Duncan, Stewart. 'Toland, Leibniz, and Active Matter.' Oxford Studies in Early Modern Philosophy. 6 (2012): 249-78.

---. 'Leibniz’s Mill Arguments Against Materialism.' Philosopbical Quarterly. 62 (2012): 250-72.

Garber, Daniel. Leibniz: Body, Substance, Monad. Oxford: Oxford University Press, 2009. 
Garber, Daniel, John Henry, Lynn Joy, and Alan Gabbey. 'New Doctrines of Body and its Powers, Place, and Space.' The Cambridge History of Seventeenth-Century Philosophy. Ed. Daniel Garber and Michael Ayers. Cambridge: Cambridge University Press, 1998. 553-623.

Harris, James. OfLiberty and Necessity: The Free Will Debate in Eighteenth-Century British Philosophy. Oxford: Clarendon, 2005.

Hartz, Glenn. Leibniz's Final System: Monads, Matter, and Animals. London: Routledge, 2007. Henry, John. 'Occult Qualities and the Experimental Philosophy: Active Principles in PreNewtonian Matter 'Theory.' History of Science. 24 (1986): 335-81.

Hobbes, Thomas. 'An Answer to Bishop Bramhall's Book, called "The Catching of the Leviathan."” The English Works of Thomas Hobbes. Vol. 4 Ed. William Molesworth. London: John Bohn, 1840. 279-384.

---. De Corpore. Elementorum Philosopiae Sectio Prima. Ed. K. Schuhmann. Paris: Vrin, 2000.

---. Elements of Philosophy, The First Section, Concerning Body. London: 1656. (English translation of Hobbes’s 1655 De Corpore.)

---. Leviathan. Ed. Noel Malcolm. Oxford: Clarendon, 2012.

---. The Elements of Law, Natural and Politic. Ed. J.C.A. Gaskin. Oxford: Oxford University Press, 1994.

Hume, David. A Treatise of Human Nature. Ed. David Fate Norton and Mary J. Norton. Oxford: Oxford University Press, 2001.

Jackson, Nicholas. Hobbes, Bramball and the Politics of Liberty and Necessity: A Quarrel of the Civil Wars and Interregnum. Cambridge: Cambridge University Press, 2007.

Janiak, Andrew. Newton as Philosopher. Cambridge: Cambridge University Press, 2008. 
Janiak, Andrew and Eric Schliesser, eds. Interpreting Newton. Cambridge: Cambridge University Press, 2012.

Leibniz, G.W. Die Werke von Leibniz. Vol. 8. Ed. Onno Klopp. Hanover: Klindworth's Verlag. 1873.

---. Philosophical Essays. Trans. Roger Ariew and Daniel Garber. Indianapolis: Hackett, 1989.

---. Leibniz's 'New System' and Associated Contemporary Texts. Trans. R. S. Woolhouse and Richard Francks. Oxford: Clarendon, 1997.

---. The Shorter Leibniz, Texts. Trans. Lloyd Strickland. London: Continuum, 2006.

Locke, John. An Essay Concerning Human Understanding. Ed. P.H. Nidditch. Oxford: Clarendon, 1975.

Lodge, Paul. “Leibniz’s Mill Argument Against Mechanical Materialism Revisited”. Ergo. 1 (2014): 79-99.

LoLordo, Antonia. Pierre Gassendi and the Birth of Early Modern Philosophy. Cambridge: Cambridge University Press, 2007.

Malebranche, Nicolas. Philosophical Selections. Ed. Steven Nadler. Indianapolis: Hackett, 1992.

---. The Search After Truth. Trans. Thomas M. Lennon and Paul J. Olscamp. Columbus: Ohio State University Press, 1980.

More, Henry. The Immortality of the Soul. London: 1659.

Newton, Isaac. The Principia. Trans. I. Bernard Cohen and Anne Whitman. Berkeley: University of California Press, 1999.

Reid, Jasper. The Metaphysics of Henry More. Dordrecht: Springer, 2012.

Rozemond, Marleen. 'Mills Can't Think: Leibniz's Approach to the Mind-Body Problem.' Res Philosophica. 91:1. (2014): 1-28. 
Toland, John. Letters to Serena. London: 1704.

Wilson, Margaret Dauler. Ideas and Mechanism. Princeton: Princeton University Press, 1999. 